\title{
Identification of new gonadotrophin-releasing hormone partial agonists
}

\author{
Alfredo Leaños-Miranda ${ }^{1,2}$, Alfredo Ulloa-Aguirre ${ }^{1,2}$, \\ Laura A Cervini ${ }^{3}$, Jo Ann Janovick', Jean Rivier ${ }^{3}$ \\ and P Michael Conn ${ }^{1,2}$ \\ 'Oregon National Primate Research Center and Departments of Physiology and Pharmacology and Cell and Developmental Biology, \\ Oregon Health and Science University, 505 NW 185th Avenue, Beaverton, Oregon 97006, USA \\ 2 Research Unit in Reproductive Medicine, Hospital de Ginecobstetricia 'Luis Castelazo Ayala', IMSS, Río Magdalena 286-6 ${ }^{\circ}$ piso, \\ México 10101, Mexico \\ ${ }^{3}$ The Salk Institute, La Jolla, California 92037, USA \\ (Requests for offprints should be addressed to P M Conn at Oregon National Primate Research Center; Email: connm@ohsu.edu)
}

\begin{abstract}
$\mathrm{GnRH}$ agonists or antagonists are currently utilized as therapeutic agents in a number of diseases. A side-effect of prolonged treatment with GnRH analogues is hypoestrogenism. In this study, we tested the in vitro potency of different GnRH analogues originally found to be partial agonists (i.e. analogues with decreased efficacy for activating or stimulating their cognate receptor) as well as novel analogues, to identify compounds that might potentially be useful for partial blockade of gonadotrophin release. Cultured COS-7 cells transiently expressing the rat or human GnRH receptor (GnRHR) were exposed to increasing concentrations $\left(10^{-8}\right.$ to $\left.10^{-5} \mathrm{M}\right)$ of $\mathrm{GnRH}$ analogues (c(4-10) $\left[\mathrm{Asp}^{4}, \mathrm{DNal}^{6}, \mathrm{Dpr}^{10}\right]-\mathrm{GnRH} ; \quad \mathrm{c}(4-10)$ $\left[\mathrm{Dpr}^{4}, \mathrm{DNal}^{6}, \mathrm{Asp}^{10}\right]-\mathrm{GnRH} ; \quad \mathrm{c}(4-10)\left[\mathrm{Cys}^{4,10}, \mathrm{DNal}^{6}\right]-$ GnRH; c[ $\left[\mathrm{Eaca}^{1}{ }^{1} \mathrm{DNal}^{6}\right]-\mathrm{GnRH} ; \mathrm{c}\left[\mathrm{Gly}^{1}, \mathrm{DNal}^{6}\right]-\mathrm{GnRH}$; c $\left[\mathrm{BAl}^{1}{ }^{1}, \mathrm{DTrp}^{6}\right]-\mathrm{GnRH}$; c $\left[\mathrm{Dava}^{1}{ }^{,} \mathrm{DNal}^{6}\right]-\mathrm{GnRH}$; c[Gaba ${ }^{1}$, $\left.\mathrm{DNal}^{6}\right]-\mathrm{GnRH}$ ), and the ability of these analogues to provoke or antagonize GnRH-stimulated inositol phosphate production was assessed.

With both human and rat GnRHRs, c[Eaca $\left.{ }^{1}, \mathrm{DNal}^{6}\right]-$ GnRH, c $\left[\mathrm{Gly}^{1}{ }^{1} \mathrm{DNal}^{6}\right]-\mathrm{GnRH}, \mathrm{c}\left[\beta \mathrm{Bla}^{1}, \mathrm{DTrp}^{6}\right]-\mathrm{GnRH}$ and
\end{abstract}

c[Dava $\left.{ }^{1}, \mathrm{DNal}^{6}\right]-\mathrm{GnRH}$ exhibited partial agonist activity (35-87\% of the maximal efficacy shown by $10^{-6} \mathrm{M}$ $\mathrm{GnRH}$ ), whereas $c\left[\mathrm{Gaba}^{1}, \mathrm{DNal}^{6}\right]-\mathrm{GnRH}$ behaved as a partial agonist with the human GnRHR and as full agonist with the rat GnRHR. c(4-10) $\left[\mathrm{Asp}^{4}, \mathrm{DNal}^{6}, \mathrm{Dpr}^{10}\right]$ GnRH and c(4-10) $\left[\mathrm{Dpr}^{4}, \mathrm{DNal}^{6}, \mathrm{Asp}^{10}\right]-\mathrm{GnRH}$ exhibited full antagonist activity with both GnRHRs, and c(4-10) $\left[\mathrm{Cys}^{4,10}, \mathrm{DNal}^{6}\right]-\mathrm{GnRH}$ was a weak, partial agonist with the human GnRHR and a full antagonist with the rat GnRHR. With the exception of $c\left[\mathrm{Gaba}^{1}, \mathrm{DNal}^{6}\right]-\mathrm{GnRH}$ stimulation of the human GnRHR, and $c\left[\mathrm{Dava}^{1}, \mathrm{DNal}^{6}\right]-$ $\mathrm{GnRH}$ and $c\left[\mathrm{Gaba}^{1}, \mathrm{DNal}^{6}\right]-\mathrm{GnRH}$ stimulation of the rat GnRHR, all partial agonists also exhibited antagonist activity in the presence of the exogenous full agonist.

The results demonstrate that structurally similar analogues display variable potencies and efficacies in vitro for a specific GnRHR as well as for the human versus the rat GnRHR. Their ultimate in vivo usefulness to treat clinical conditions in which complete suppression of gonadotroph activity is not required remains to be investigated.

Journal of Endocrinology (2006) 189, 509-517

\section{Introduction}

Gonadotrophin-releasing hormone $(\mathrm{GnRH})$ is a key regulator of reproductive functions. This decapeptide is produced and secreted by specialized neurons predominantly located in the arcuate nucleus of the mediobasal hypothalamus and in the pre-optic area of the anterior hypothalamus (Conn \& Crowley 1991, Ulloa-Aguirre \& Timossi 2000). GnRH specifically interacts with its membrane receptor $(R)$ in the gonadotrophs leading to both synthesis and secretion of the gonadotrophins luteinizing hormone (LH) and follicle-stimulation hormone (FSH) (Conn et al. 1995, Millar et al. 2004). The release of GnRH from hypothalamic neurons occurs in a pulsatile manner, a feature that allows physiologic secretion of gonadotrophins (Santen \& Bardin 1973, Knobil 1974). In fact, intermittent exposure of the GnRHR to the releasing hormone is important from a functional point of view, since it prevents desensitization (refractoriness) of the gonadotroph to a subsequent stimulus and allows for occurrence of the distinct rates and patterns of synthesis and release of $\mathrm{LH}$ and FSH that follow GnRH exposure (Belchetz et al. 1978). 
The ability to suppress reproductive function by the continuous stimulation of the GnRHR by agonists (desensitization), or through continuous occupancy of the GnRHR with antagonists, has led to the development of GnRH agonists and antagonists currently employed as key therapeutic agents in a number of diseases, including cancer (Conn \& Crowley 1991, Filicori 1994, Emons et al. 1997, Kiesel et al. 2002, Chabbert-Buffet et al. 2003). Analogues that capitalize on both mechanisms have been highly effective in suppressing the serum levels of gonadotrophins and steroid hormone production, provoking a chemical castration (Cusan et al. 1979, Conn \& Crowley 1991, Filicori 1994, Emons et al. 1997, Ulloa-Aguirre \& Timossi 2000, Kiesel et al. 2002, Chabbert-Buffet et al. 2003). Nevertheless, complete and prolonged suppression of gonadotrophin secretion and gonadal steroids by $\mathrm{GnRH}$ analogues frequently results in symptoms of oestrogen deficiency (DeFazio et al. 1983, Matta et al. 1987, Johansen et al. 1988, Tummon et al. 1988, Conn \& Crowley 1991, Fogelman 1992, Pierce et al. 2000). Furthermore, the use of lower doses of GnRH-agonist analogues to allow for some residual pituitary-gonadal function has failed to fully overcome this adverse effect (Conn \& Crowley 1991). In this scenario, partial $\mathrm{GnRH}$ agonists (i.e. agonists that exhibit decreased efficacy for activating or stimulating their cognate receptor thereby eliciting lower maximal responses than a full agonist) may potentially be useful in those conditions in which complete suppression of gonadal steroid secretion is not required, particularly when longterm treatment is needed and hormonal replacement add-back therapy is contraindicated or proven to be inefficient (Pierce et al. 2000).

Among the thousands of $\mathrm{GnRH}$ analogues described in the literature, very few exhibited partial agonism and were forgotten once better antagonists became available. The first observation of a GnRH partial agonist ([Gly $\left.{ }^{2}\right]-$ $\mathrm{GnRH}$ ) led to the design of the first GnRH antagonist, des-His ${ }^{2}-$ GnRH (Vale et al. 1972). Interestingly, substitutions other than Gly at position 2 of GnRH (such as L-amino acids) led to low potency full agonists whereas substitutions by a D-amino acid led to full antagonists (Karten \& Rivier 1986). It is only with the synthesis of cyclic GnRH analogues that a new family of GnRH partial agonists was discovered. This family encompasses sequences that are $\mathrm{N}$ - to C-terminally cyclized (Rivier et al. 1986). In view of the fact that cyclization could bring partial agonism, we synthesized a second family of analogues characterized by sequences that are cyclized through the side chains of amino acids at positions 4 and 10. Three members of the first family were described in a preliminary report. $c\left[\mathrm{Eaca}^{1}, \mathrm{DNal}{ }^{6}\right]-\mathrm{GnRH}, c\left[\beta \mathrm{Ala}^{1}\right.$, $\left.\mathrm{DNal}^{6}\right]-\mathrm{GnRH}$ and $\mathrm{c}\left[\mathrm{Gaba}^{1}, \mathrm{DNal}^{6}\right]-\mathrm{GnRH}$ are partial agonists with high binding affinity (Rivier et al. 1986). Members of the second family are disclosed here for the first time and were tested for their in vitro properties.

\section{Materials and Methods}

\section{Materials}

Synthetic GnRH was provided by the NIDDK National Hormone and Peptide Program through Dr A F Parlow (Torrance, CA, USA). The GnRH agonist, Buserelin ([D-tert-butyl-Ser ${ }^{6}$,des-Gly ${ }^{10}$,Pro ${ }^{9}$-ethylamide $\left.]-G n R H\right)$ was a kind gift of Hoechst-Roussel Pharmaceutical (Somerville, NJ, USA). The following peptides were synthesized at the Salk Institute (La Jolla, CA, USA): c (4-10) $\left[\mathrm{Cys}^{4,10}, \mathrm{DNal}^{6}\right]-\mathrm{GnRH}, \mathrm{c}\left[\mathrm{BAla}^{1}, \mathrm{DTrp}^{6}\right]-\mathrm{GnRH}$, c $\left[\mathrm{Dava}^{1}, \mathrm{DNa}^{6}\right]-\mathrm{GnRH}, \mathrm{c}\left[\mathrm{Gly}^{1}{ }^{1}, \mathrm{DNal}^{6}\right]-\mathrm{GnRH}, \mathrm{c}\left[\mathrm{Eaca}^{1}{ }^{1}\right.$, $\left.\mathrm{DNal}^{6}\right]-\mathrm{GnRH}, \quad c\left[\mathrm{Gaba}^{1}, \mathrm{DNal}^{6}\right]-\mathrm{GnRH}, c(4-10)\left[\mathrm{Dpr}^{4}\right.$, $\left.\mathrm{DNal}^{6}, \mathrm{Asp}^{10}\right]-\mathrm{GnRH}$ and $\mathrm{c}(4-10)\left[\mathrm{Asp}^{4}, \mathrm{DNal}^{6}, \mathrm{Dpr}^{10}\right]-$ GnRH. Peptides were diluted in PBS/10\% dimethylsulphoxide (DMSO) at a $1 \mu \mathrm{g} / \mu \mathrm{l}$ concentration and the stocks were stored frozen at $-70{ }^{\circ} \mathrm{C}$ until they were used. The expression vector pcDNA3·1, Dulbecco's modified Eagle's medium (DMEM), OPTI-MEM, lipofectamine and PCR reagents were purchased from Invitrogen. Restriction enzymes, modified enzymes and competent cells for subcloning were purchased from Promega. Other reagents were of the highest degree of purity available from commercial sources.

\section{Vectors}

Wild-type (WT) rat (r) GnRHR cDNA in pcDNA1 was subcloned into pcDNA3.1 at BamHI and XhoI restriction enzyme sites. The WT human (h) GnRHR cDNA in pcDNA3 was also subcloned into pcDNA3.1 at KpnI and $\mathrm{XbaI}$ restriction enzyme sites.

\section{Transient transfection of COS-7 cells}

WT $\mathrm{rGnRH}$ and hGnRH receptors were transiently expressed in COS-7 cells. COS-7 cells were maintained at $37{ }^{\circ} \mathrm{C}$ in growth medium (DMEM) containing $10 \%$ fetal calf serum (FCS) (Life Technologies) and $20 \mu \mathrm{g} / \mathrm{ml}$ gentamicin (Gemini Bioproducts, Calabasas, CA, USA) in a humidified $5 \% \mathrm{CO}_{2}$ atmosphere. The cells $\left(10^{5}\right.$ cells/ well) were seeded in 24-well plates (Costar, Cambridge, MA, USA). Twenty-four hours after plating, the cells were transfected with $0 \cdot 075 \mu \mathrm{g}$ (for inositol phosphate (IP) production) or $0 \cdot 1 \mu \mathrm{g}$ (for ${ }^{125}$ I-labelled buserelin binding) of cDNA/well using $2 \mu \mathrm{l}$ lipofectamine in $0.25 \mathrm{ml}$ OPTIMEM. Five hours later, $0.25 \mathrm{ml}$ DMEM containing $20 \%$ FCS was added to each well. Twenty-four hours after the start of transfection the medium was replaced with fresh growth medium and the cells were allowed to grow for another $24 \mathrm{~h}$ before the functional assay (IP production).

\section{Measurement of IP production}

Forty-eight hours after the start of transfection, COS-7 cells transfected with the WT rat or human GnRH 

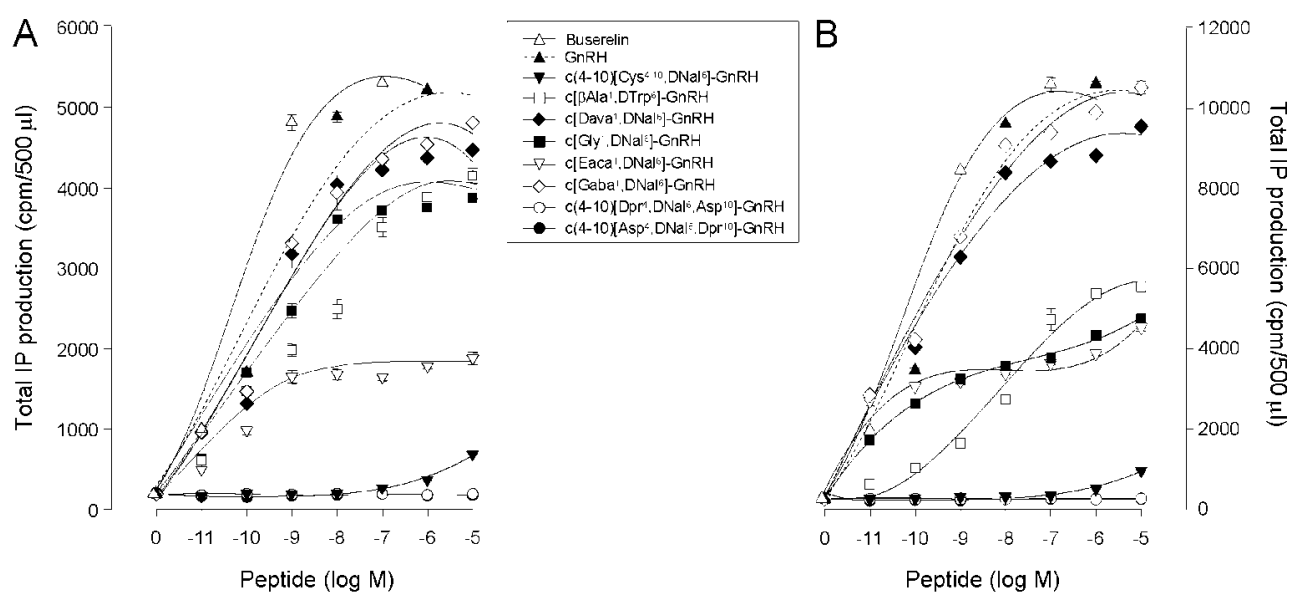

Figure 1 Stimulation of IP production in transiently transfected COS-7 cells with the WT hGnRHR (A) or WT rGnRHR (B) by different GnRH peptide analogues. IP production was determined after a 2-h incubation in the presence of increasing concentrations of each peptide as described in Materials and Methods. Data are the means \pm S.E.M. of a representative experiment performed in triplicate and repeated three or more times.

receptor cDNAs were washed twice with DMEM/0.1\% BSA and intracellular inositol lipids were labelled with $4 \mu \mathrm{Ci} / \mathrm{ml}\left[{ }^{3} \mathrm{H}\right]$ myo-inositol in DMEM (inositol free) for $18 \mathrm{~h}$ at $37^{\circ} \mathrm{C}$. After the preloading period, the cells were washed twice in DMEM (inositol free) containing $5 \mathrm{mM}$ $\mathrm{LiCl}$ and incubated for $2 \mathrm{~h}$ at $37^{\circ} \mathrm{C}$ in the absence or presence of GnRH $\left(10^{-10}, 10^{-8}\right.$ and $\left.10^{-6} \mathrm{M}\right)$, buserelin $\left(10^{-11}, 10^{-9}\right.$ and $\left.10^{-7} \mathrm{M}\right)$ or increasing concentrations $\left(10^{-11}\right.$ to $\left.10^{-5} \mathrm{M}\right)$ of the different $\mathrm{GnRH}$ analogues in DMEM (inositol free) $/ \mathrm{LiCl}$ prepared by serial dilutions of the original stocks in DMEM. Alternatively, transfected cells were co-incubated with $10^{-8} \mathrm{M}$ GnRH and $10^{-8}$ to $10^{-5} \mathrm{M}$ concentrations of the GnRH analogues. At the end of the incubation period, the medium was removed and $1 \mathrm{ml}$ of $0 \cdot 1 \mathrm{M}$ formic acid was added to each well. The cells were frozen at $-20{ }^{\circ} \mathrm{C}$ until assayed for IP production. IP accumulation was determined by Dowex anion-exchange chromatography and liquid scintillation spectroscopy as previously described (Huckle \& Conn 1987).

\section{Receptor binding assay}

COS-7 cells were transiently transfected with the WT rat or human GnRH receptor cDNAs as described above. Twenty-seven hours after the start of transfection, the cells were washed twice with warm DMEM/0.1\% BSA/ $10 \mathrm{mM}$ HEPES buffer and cultured in DMEM for $18 \mathrm{~h}$ before the addition of ${ }^{125}$ I-buserelin (specific activity, $700 \mu \mathrm{Ci} / \mu \mathrm{g} ; \sim 10^{6}$ c.p.m. $/ 0.5 \mathrm{ml} ; \mathrm{pH} 7 \cdot 4$ ). Cells were incubated at room temperature for $90 \mathrm{~min}$ in the presence or absence of excess $(2 \mu \mathrm{M}) \mathrm{GnRH}$ plus ${ }^{125}$ I-buserelin or ${ }^{125} \mathrm{I}$-buserelin plus increasing concentrations $\left(10^{-10}\right.$ to $10^{-5} \mathrm{M}$ ) of $\mathrm{GnRH}$ or the different GnRH analogues.
Thereafter, the medium was removed, the plates containing the cells were placed on ice, washed twice with ice-cold PBS; the cells were then solubilized by the addition of $0 \cdot 2 \mathrm{M} \mathrm{NaOH} / 0 \cdot 1 \% \mathrm{SDS}$. Aliquots of samples were then transferred to glass tubes and counted in a gamma counter (Packard Instruments, Downers Grove, IL, USA). Specific binding was calculated by subtracting non-specific binding (binding measured in the presence of $2 \mu \mathrm{M} \mathrm{GnRH}$ ) from total binding (no GnRH added).

\section{Statistical analysis}

Data shown are the means \pm S.E.M. from three or more experiments in triplicate incubations. In all experiments, the S.D was typically less than $10 \%$ of the corresponding mean. Within-group comparisons were made by one-way ANOVA followed by Tukey's HSD test; between-group comparisons were made using Student's unpaired $t$ test. Values of $P<0 \cdot 05$ were considered statistically significant. Half-maximal doses $\left(\mathrm{ED}_{50}\right)$ and concentrations giving $50 \%$ of maximal inhibition $\left(\mathrm{IC}_{50}\right)$ were calculated using the software Origin 7.0 (OriginLab Co, Northampton, MA, USA) and fitted to a sigmoidal dose-response curve.

\section{Results}

Stimulation of IP turnover by GnRH and GnRH analogues

Synthetic GnRH, and its metabolically stable superagonist buserelin, provoked concentration-dependent increments in IP production by COS-7 cells transiently expressing either the WT rGnRHR or the WT hGnRHR (Fig. 1). 
Table $1 \mathrm{ED}_{50}$ and $\mathrm{IC}_{50}$ values of different GnRH peptide analogues in COS-7 cells transiently expressing the WT rGnRHR or WT hGnRHR

$\mathrm{ED}_{50}$ for agonist effect $(\mathrm{nM})$

\begin{tabular}{l} 
hGnRHR \\
\hline $0 \cdot 04 \pm 0 \cdot 01^{\mathrm{a}}$ \\
$0 \cdot 42 \pm 0 \cdot 06^{\mathrm{b}, \mathrm{c}, \mathrm{g} *}$ \\
- \\
- \\
$941 \pm 194^{\mathrm{e}}$ \\
$0 \cdot 17 \pm 0 \cdot 04^{\mathrm{d} *}$ \\
$0 \cdot 19 \pm 0 \cdot 02^{\mathrm{c}, \mathrm{d}}$ \\
$1 \cdot 1 \pm 0 \cdot 40^{\mathrm{d}, \mathrm{f} *}$ \\
$0 \cdot 48 \pm 0 \cdot 13^{\mathrm{c}, \mathrm{d}, \mathrm{f}}$ \\
$0 \cdot 34 \pm 0 \cdot 08^{\mathrm{f}, \mathrm{g} *}$
\end{tabular}

\begin{tabular}{ll} 
IC $_{50}$ on $10^{-8}$ GnRH (nM) \\
\hline hGnRHR
\end{tabular}

rGnRHR

\section{Peptide}

Buserelin

GnRH

$\mathrm{C}(4-10)\left[\mathrm{Asp}^{4}, \mathrm{DNal}^{6}, \mathrm{Dpr}^{10}\right]-\mathrm{GnRH}$

$\mathrm{C}(4-10)\left[\mathrm{Dpr}^{4}, \mathrm{DNal}^{6}, \mathrm{Asp}^{10}\right]-\mathrm{GnRH}$

$\mathrm{C}(4-10)\left[\mathrm{Cys}^{4,10}, \mathrm{DNal}^{6}\right]-\mathrm{GnRH}$

c[Eaca $\left.{ }^{1}, \mathrm{DNal}^{6}\right]-\mathrm{GnRH}$

$\mathrm{C}\left[\mathrm{Gly}^{1}, \mathrm{DNal}^{6}\right]-\mathrm{GnRH}$

c[BAla $\left.{ }^{1}, \mathrm{DTrp}^{6}\right]-\mathrm{GnRH}$

$\mathrm{C}\left[\mathrm{Dava}^{1}, \mathrm{DNal}^{6}\right]-\mathrm{GnRH}$

$\mathrm{C}\left[\mathrm{Gaba}^{1}, \mathrm{DNal}^{6}\right]-\mathrm{GnRH}$

\begin{tabular}{c}
\hline $0 \cdot 05 \pm 0 \cdot 01^{\mathrm{a}, \mathrm{f}}$ \\
$1 \cdot 5 \pm 0 \cdot 48^{\mathrm{b}}$ \\
- \\
- \\
$3860 \pm 1159^{\mathrm{c}}$ \\
$0 \cdot 02 \pm 0 \cdot 01^{\mathrm{a}}$ \\
$0 \cdot 11 \pm 0 \cdot 02^{\mathrm{d}}$ \\
$13 \cdot 1 \pm 1 \cdot 80^{\mathrm{e}}$ \\
$0 \cdot 39 \pm 0 \cdot 10^{\mathrm{d}}$ \\
$0 \cdot 05 \pm 0 \cdot 01^{\mathrm{f}}$
\end{tabular}

$$
\begin{gathered}
- \\
57 \pm 9^{\mathrm{a} *} \\
147 \pm 27^{\mathrm{b} *} \\
308 \pm 35^{\mathrm{c} *} \\
- \\
- \\
- \\
-
\end{gathered}
$$$$
\begin{gathered}
- \\
14 \pm 3^{a} \\
18 \pm 3^{a} \\
85 \pm 19^{b} \\
- \\
- \\
- \\
-
\end{gathered}
$$

Data are means \pm S.E.M. of three independent experiments in triplicate incubations. Means identified by different superscript letters in the same column are significantly $(P<0 \cdot 05)$ different. ${ }^{*} P<0 \cdot 05$ vs rat GnRHR system. Gaba, $\gamma$-aminobutyric acid; Eaca, $\varepsilon$-aminocaproic acid; Dava, $\delta$-aminovaleric acid; $\mathrm{DNal}=\beta$-(2-napthyl)-D-alanine; Dpr, 2,3-diaminopropionic acid.

Table 1 shows the $\mathrm{ED}_{50}$ values of $\mathrm{GnRH}$, buserelin and the GnRH peptides tested. In the human GnRHR system, $\quad c\left[\mathrm{Eaca}^{1}, \mathrm{DNal}^{6}\right]-\mathrm{GnRH}$ and $c\left[\mathrm{Gly}^{1}, \mathrm{DNal}^{6}\right]-$ GnRH presented slightly lower $\mathrm{ED}_{50}$ values than $\mathrm{GnRH}$ but considerably reduced fractions of maximal response (Table 2). The $\mathrm{ED}_{50}$ values of $\mathrm{c}\left[\mathrm{Dava}^{1}, \mathrm{DNa}^{6}\right]-\mathrm{GnRH}$ and $c\left[\mathrm{Gaba}^{1}, \mathrm{DNal}^{6}\right]-\mathrm{GnRH}$ were similar to that shown by GnRH. Compared with GnRH, c[Eaca $\left.{ }^{1}, \mathrm{DNal}^{6}\right]-$ $\mathrm{GnRH}, c\left[\mathrm{Gly}^{1}, \mathrm{DNal}^{6}\right]-\mathrm{GnRH}, c\left[\mathrm{Dava}^{1}, \mathrm{DNal}^{6}\right]-\mathrm{GnRH}$ and $c\left[\mathrm{Gaba}^{1}, \mathrm{DNal}^{6}\right]-\mathrm{GnRH}$ exhibited lower $\mathrm{ED}_{50}$ values than GnRH with the rGnRHR (Table 1); nevertheless, the fraction of maximal response of all of these $\mathrm{GnRH}$ peptides (except $\left.c\left[\mathrm{Gaba}^{1}{ }^{1} \mathrm{DNal}^{6}\right]-\mathrm{GnRH}\right)$ was significantly attenuated. Table 2 shows the efficacy to provoke maximal IP production and to inhibit GnRH-stimulated IP production of the different GnRH peptides. According to the responses observed in the particular receptor systems used, the operational definitions of agonist, partial agonist or antagonist were employed to define the type of activity of each analogue.

In the hGnRHR system, c(4-10)[Cys $\left.{ }^{4,10}, \mathrm{DNal}^{6}\right]-$ $\mathrm{GnRH}$ and $\mathrm{c}\left[\mathrm{Eaca}^{1}, \mathrm{DNal}^{6}\right]-\mathrm{GnRH}$ behaved as weak, partial agonists (13-35\% of the maximal response observed with GnRH or buserelin (Fig. 1A and Table 2)); c $\left[\mathrm{Gly}^{1}, \mathrm{DNal}^{6}\right]-\mathrm{GnRH}, \mathrm{c}\left[\beta \mathrm{Ala}^{1}{ }^{1} \mathrm{DTrp}^{6}\right]-\mathrm{GnRH}, \mathrm{c}\left[\mathrm{Dava}^{1}\right.$, $\left.\mathrm{DNal}^{6}\right]-\mathrm{GnRH}$ and $\mathrm{c}\left[\mathrm{Gaba}^{1}{ }^{1} \mathrm{DNal}^{6}\right]-\mathrm{GnRH}$ were more efficacious partial agonists (73-87\% efficacy). c(4-10) $\left[\mathrm{Asp}^{4}, \mathrm{DNal}{ }^{6}, \mathrm{Dpr}^{10}\right]-\mathrm{GnRH}$ and $\mathrm{c}(4-10)\left[\mathrm{Dpr}^{4}, \mathrm{DNal}^{6}\right.$, Asp $\left.^{10}\right]-G n R H$ had no effect on IP production in this receptor system (Tables 1 and 2). In the rGnRHR system, c $\left[\mathrm{Eaca}^{1}, \mathrm{DNal}^{6}\right]-\mathrm{GnRH}, \mathrm{c}\left[\mathrm{Gly}^{1}{ }^{1}, \mathrm{DNal}^{6}\right]-\mathrm{GnRH}, \mathrm{c}\left[\mathrm{BAla}^{1}\right.$, DTrp $\left.^{6}\right]-G n R H$, and $c\left[\right.$ Dava $\left.^{1}, \mathrm{DNal}^{6}\right]-$ GnRH behaved as partial agonists on GnRHR activation $(44-87 \%$ of the maximal efficacy shown by either $10^{-6} \mathrm{M}$ GnRH or $10^{-7} \mathrm{M}$ buserelin); c $\left[\mathrm{Gaba}^{1}{ }^{1}, \mathrm{DNal}^{6}\right]-\mathrm{GnRH}$ exhibited the highest efficacy (98\% of the efficacy shown by GnRH or buserelin) in this particular GnRHR system and thus behaved as a full agonist (Table 2). No agonist activity was detected for the $\mathrm{c}(4-10)\left[\mathrm{Asp}^{4}, \mathrm{DNal}^{6}, \mathrm{Dpr}^{10}\right]-\mathrm{GnRH}$, c(4-10) $\left[\mathrm{Dpr}^{4}, \mathrm{DNal}^{6}, \mathrm{Asp}^{10}\right]-\mathrm{GnRH}$ and c(4-10) $\left[\mathrm{Cys}^{4,10}\right.$, $\left.\mathrm{DNal}^{6}\right]$-GnRH compounds (Fig. 1B).

\section{Inhibition of GnRH-stimulated IP accumulation by GnRH analogues}

In both GnRHR systems, c(4-10) $\left[\mathrm{Asp}^{4}, \mathrm{DNal}^{6}, \mathrm{Dpr}^{10}\right]-$ GnRH and c(4-10)[Dpr $\left.{ }^{4}, \mathrm{DNal}^{6}, \mathrm{Asp}^{10}\right]-\mathrm{GnRH}$ behaved as full antagonists of GnRH (Table 2). c(4-10) $\left[\mathrm{Cys}^{4,10}, \mathrm{DNal}^{6}\right]-\mathrm{GnRH}$ behaved as a strong antagonist with the rGnRHR, but not in the hGnRHR system (Fig. 2A and B, and Tables 1 and 2). In the rGnRHR system, $\quad c\left[\mathrm{Eaca}^{1}, \mathrm{DNal}^{6}\right]-\mathrm{GnRH}$ and $\mathrm{c}^{6}\left[\mathrm{Gly}^{1}, \mathrm{DNal}^{6}\right]-$ GnRH inhibited (by 30-40\%) the $10^{-8} \mathrm{M}$ GnRHmediated IP response, whereas in the hGnRHR system, only the $c(4-10)\left[\mathrm{Cys}^{4,10}, \mathrm{DNal}^{6}\right]-\mathrm{GnRH}$ and $c\left[\mathrm{Eaca}^{1}\right.$, $\left.\mathrm{DNal}^{6}\right]-\mathrm{GnRH}$ analogues showed a similar effect. In contrast to the effects observed with the rGnRHR, in the human receptor system, $\mathrm{c}\left[\mathrm{Gly}^{1}{ }^{1} \mathrm{DNal}{ }^{6}\right]-\mathrm{GnRH}$ marginally (15\%) inhibited GnRH stimulation of IP accumulation. In both GnRHRs, c $\left[\mathrm{BAla}^{1}, \mathrm{DTrp}{ }^{6}\right]-\mathrm{GnRH}, \mathrm{c}\left[\mathrm{Dava}^{1}, \mathrm{DNal}^{6}\right]-$ $\mathrm{GnRH}$ and $c\left[\mathrm{Gaba}^{1}, \mathrm{DNal}^{6}\right]-\mathrm{GnRH}$ showed substantially decreased or null efficacy to inhibit GnRH-stimulated IP production.

\section{Effect of GnRH analogues on ${ }^{125}$ I-buserelin binding}

All GnRH peptides inhibited specific ${ }^{125}$ I-buserelin binding in a dose-related manner (Fig. 3). Relative receptor levels were higher for the rGnRHR system $(62 \cdot 0 \pm$ $4.7 \mathrm{pmol} / 10^{5}$ cells $)$ than in the hGnRHR system $(1 \cdot 2 \pm$ $0.22 \mathrm{pmol} / 10^{5}$ cells). The potency of the peptides to inhibit binding of radiolabelled buserelin (Table 3) did not absolutely correlate with IP production in response to buserelin (compare Figs 1 and 3). In fact, 

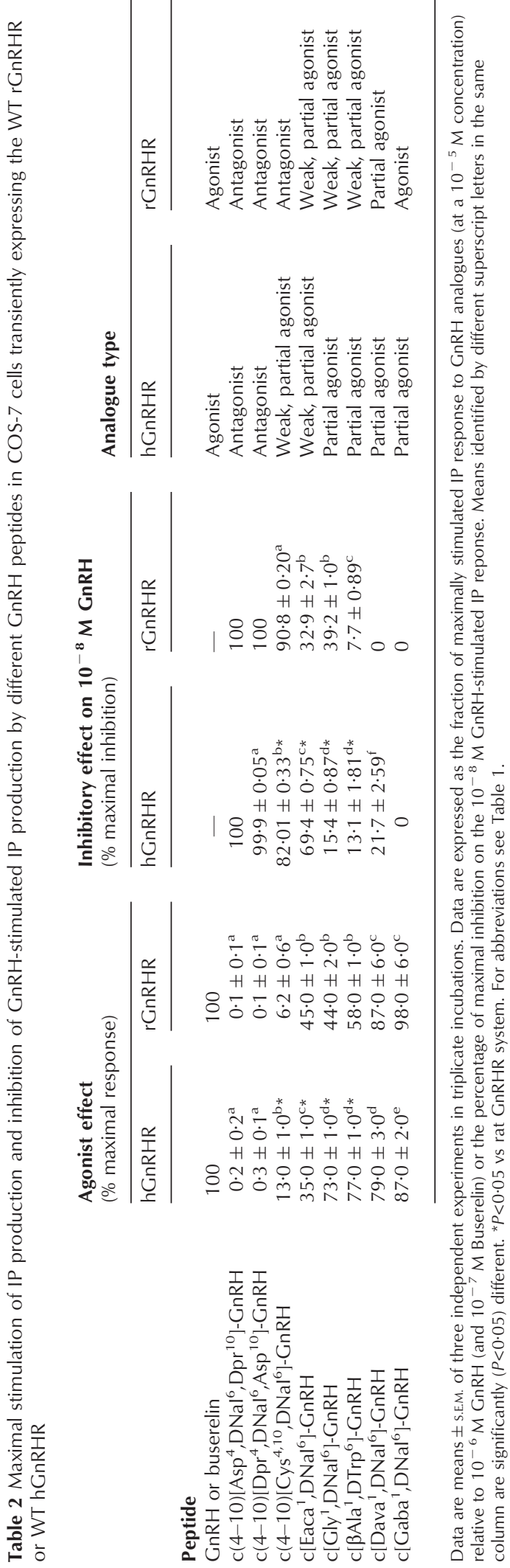

the full antagonists $c(4-10)\left[\mathrm{Asp}^{4}, \mathrm{DNal}^{6}, \mathrm{Dpr}^{10}\right]-\mathrm{GnRH}$ and $\mathrm{c}(4-10)\left[\mathrm{Dpr}^{4}, \mathrm{DNal}^{6}, \mathrm{Asp}^{10}\right]-\mathrm{GnRH}$ were the most potent analogues for inhibiting ${ }^{125} \mathrm{I}$-buserelin binding with both GnRHR systems (Table 3).

\section{Discussion}

The effects of GnRH are mediated via $\mathrm{LH}$ and FSH released in response to the releasing decapeptide and via sex steroid hormones secreted by the gonads in response to gonadotrophin stimulation. Full agonists used as desensitizing agents render the target cell refractory, whereas antagonists block the binding site of the GnRHR to endogenous occupancy without coupling to the receptor or triggering signal transduction (Cusan et al. 1979, Conn \& Crowley 1991, Ortmann et al. 2002). Either approach generally results in oestrogen deficiency, thereby limiting their usefulness as therapeutic agents when partial desensitization is desired.

In contrast to full antagonists, which bind equally to both the inactive and active receptor conformations, partial agonists are characterized by exhibiting higher affinity for the active conformation than for its inactive conformation, but with less selectivity towards the active conformation than the strong agonists (Brink et al. 2004). At high concentrations, partial agonists elicit a lower maximal response in a particular biological system than a defined standard and may act either as a functional agonist or a functional antagonist, depending on the levels of the naturally occurring agonist (Lipworth \& Grove 1997, Pliska 1999, Lieberman 2004). Because of their particular selectivity towards different receptor states and low potential to provoke side-effects, these compounds currently represent attractive options in the treatment of a variety of diseases (Callahan 2002, Frolund et al. 2002, Doggrell 2004, Gao \& Jacobson 2004, Lieberman 2004, Reynolds 2004, Bolonna \& Kerwin 2005).

In the present study, we analyzed the in vitro effects of different GnRH peptide analogues on intracellular signalling triggered by the activation of two structurally similar GnRH receptors. Using the rGnRHR system, we identified three GnRH-antagonist analogues (c(4-10)[Asp ${ }^{4}$, $\left.\mathrm{DNal}^{6}, \mathrm{Dpr}^{10}\right]-\mathrm{GnRH}, \mathrm{c}(4-10)\left[\mathrm{Dpr}^{4}, \mathrm{DNal}^{6}, \mathrm{Asp}^{10}\right]-\mathrm{GnRH}$ and $\left.c(4-10)\left[\mathrm{Cys}^{4,10}, \mathrm{DNal}^{6}\right]-\mathrm{GnRH}\right)$ and four compounds that behaved as partial agonists (c[Eaca $\left.{ }^{1}, \mathrm{DNal}^{6}\right]-\mathrm{GnRH}$, $c\left[\mathrm{Gly}^{1}, \mathrm{DNal}^{6}\right]-\mathrm{GnRH}, \mathrm{c}\left[\mathrm{BAla}^{1}{ }^{1}, \mathrm{DTr} \mathrm{Tr}^{6}\right]-\mathrm{GnRH}$ and c $\left[\mathrm{Dava}^{1}\right.$, $\left.\left.\mathrm{DNal}^{6}\right]-\mathrm{GnRH}\right)$; these compounds, and $\mathrm{c}\left[\mathrm{Gaba}^{1}, \mathrm{DNal}^{6}\right]-$ GnRH (a full agonist at the highest concentration tested in the rGnRHR system), behave as partial agonists with the hGnRHR. With the exception of $c\left[\mathrm{Gaba}^{1}, \mathrm{DNal}^{6}\right]-$ $\mathrm{GnRH}$, and to a lesser extent c $\left[\mathrm{Gly}^{1}, \mathrm{DNa}^{6}\right]-\mathrm{GnRH}$, c $\left[\beta_{A l a}{ }^{1}, \mathrm{DTrp}^{6}\right]-\mathrm{GnRH}$ and $\mathrm{c}\left[\mathrm{Dava}^{1}{ }^{1}, \mathrm{DNal}^{6}\right]-\mathrm{GnRH}$ with the hGnRHR, and $c\left[\beta \mathrm{Bla}^{1}, \mathrm{DTrp}^{6}\right]-\mathrm{GnRH}, c\left[\mathrm{Dava}^{1}\right.$, $\left.\mathrm{DNal}^{6}\right]-\mathrm{GnRH}$ and $\left.\mathrm{c}^{6} \mathrm{Gaba}^{1}, \mathrm{DNal}^{6}\right]-\mathrm{GnRH}$ in the rGnRHR system, partial GnRH agonists also exhibited 

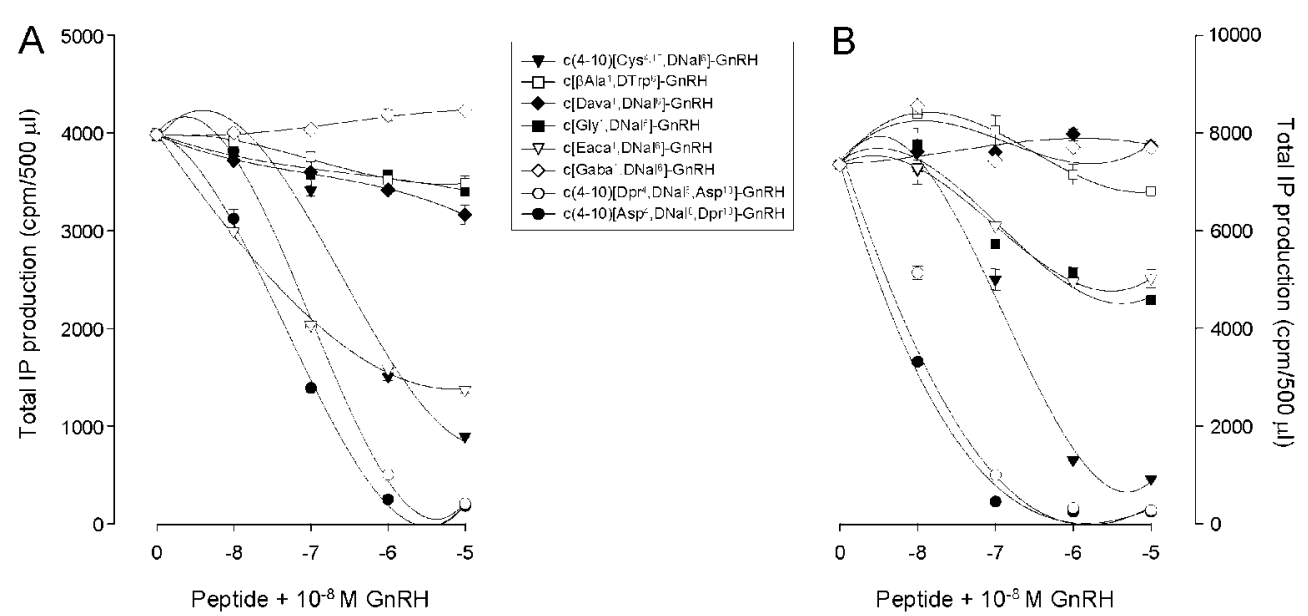

Figure 2 Inhibition of GnRH-stimulated IP production by different peptides. The peptides $\left(10^{-8}\right.$ to $\left.10^{-5} \mathrm{M}\right)$ were preincubated with $10^{-8} \mathrm{M}$ GnRH before stimulating COS-7 cells transiently transfected with the WT hGnRHR (A) or WT rGnRHR (B). IP production was determined after a 2-h incubation. Data are means \pm S.E.M. of a representative experiment performed in triplicate and repeated three or more times.

significant antagonist activity in the presence of the exogenous full agonist, which is an intrinsic pharmacologic feature of this class of compounds (Lipworth \& Grove 1997, Pliska 1999).

It was interesting to find that some of the analogues studied displayed different potencies and even differential effects when tested with the rat and human GnRHRs, which share $88 \%$ in amino acid identity (Millar et al. 2004). For example, $c\left[\mathrm{Gly}^{1}, \mathrm{DNal}^{6}\right]-\mathrm{GnRH}$ and $\mathrm{c}\left[\beta \mathrm{Ala}^{1}\right.$, DTrp $\left.{ }^{6}\right]-G n R H$ exhibited lower efficacies (fraction of maximal response, $0 \cdot 4-0 \cdot 6)$ to activate the rGnRHR than the human receptor $(0 \cdot 7-0.8$ times the efficacy of $\mathrm{GnRH})$. Furthermore, c(4-10)[Cys $\left.{ }^{4,10}, \mathrm{DNal}^{6}\right]-\mathrm{GnRH}$ behaved as a full antagonist in the rGnRHR system, whereas in the human receptor it behaved as a weak, partial agonist. Although this variability of effects may be due to differences in relative receptor levels between the two GnRHR systems, it is also possible that positioning of the analogues in each $\mathrm{GnRH}$ receptor may potentially impede an optimal interaction of the analogue with key receptor domains involved in ligand binding and/or receptor activation, thereby altering its ability to stabilize the active state of the receptor. In this scenario, subtle structural differences between these receptors would allow the agonists to drive with different efficacies the equilibrium between the inactive and active conformations in favour of the latter. In the case of $\mathrm{c}(4-10)\left[\mathrm{Cys}^{4,10}, \mathrm{DNal}^{6}\right]-$ GnRH, the weak partial agonist activity with the
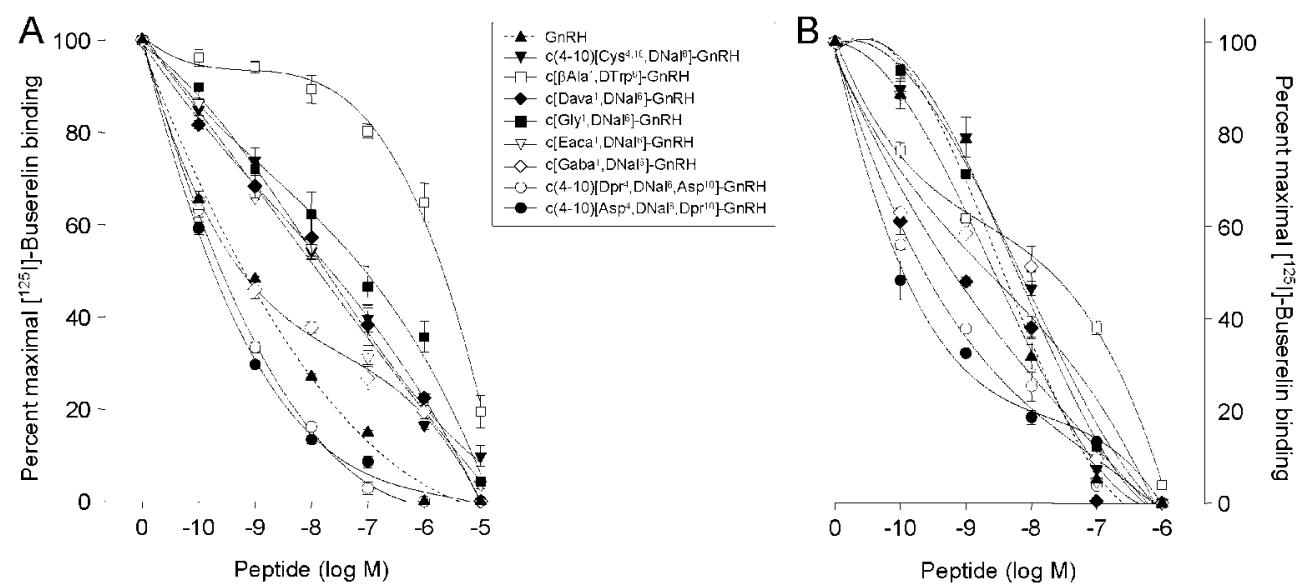

Figure 3 Inhibition of ${ }^{125}$-buserelin binding by GnRH and GnRH peptides. COS-7 cells transiently expressing the WT hGnRHR (A) or WT rGnRHR (B) were exposed to ${ }^{125}$ I-buserelin for 90 min in the presence or absence of excess $(2 \mu \mathrm{M}) \mathrm{GnRH}$ or increasing concentrations $\left(10^{-10}\right.$ to $\left.10^{-5} \mathrm{M}\right)$ of the different GnRH analogues. Data are means \pm S.E.M. of a representative experiment performed in triplicate and repeated at least three times. 
Table $3 \mathrm{IC}_{50}$ doses of $\mathrm{GnRH}$ and different $\mathrm{GnRH}$ peptide analogues to inhibit ${ }^{125}$-buserelin binding in COS-7 cells transiently expressing the WT rGnRHR or WT hGnRHR

\begin{tabular}{|c|c|c|}
\hline & $\begin{array}{l}\mathrm{IC}_{50} \text { on }{ }^{125} \text {-bus } \\
(\mathrm{nM})\end{array}$ & elin binding \\
\hline & hGnRHR & rGnRHR \\
\hline Peptide & & \\
\hline $\mathrm{GnRH}$ & $0 \cdot 36 \pm 0 \cdot 07^{\mathrm{a} *}$ & $4 \cdot 33 \pm 0 \cdot 32^{a}$ \\
\hline $\mathrm{C}(4-10)\left[\mathrm{Asp}^{4}, \mathrm{DNal}^{6}, \mathrm{Dpr}^{10}\right]-\mathrm{GnRH}$ & $0 \cdot 14 \pm 0 \cdot 01^{b *}$ & $0.04 \pm 0.01^{b}$ \\
\hline $\mathrm{C}(4-10)\left[\mathrm{Dpr}^{4}, \mathrm{DNal}^{6}, \mathrm{Asp}^{10}\right]-\mathrm{GnRH}$ & $0 \cdot 21 \pm 0 \cdot 03^{a, b_{*}}$ & $0 \cdot 08 \pm 0.01^{\mathrm{c}}$ \\
\hline $\mathrm{c}(4-10)\left[\mathrm{Cys}^{4,10}, \mathrm{DNal}^{6}\right]-\mathrm{GnRH}$ & $22 \pm 2 \cdot 80^{\mathrm{c} *}$ & $9 \cdot 2 \pm 0 \cdot 80^{\mathrm{d}}$ \\
\hline $\mathrm{c}\left[\mathrm{Eaca}^{1}, \mathrm{DNal}^{6}\right]-\mathrm{GnRH}$ & $7 \cdot 4 \pm 1 \cdot 80^{d_{*}}$ & $3 \cdot 6 \pm 0 \cdot 50^{a}$ \\
\hline $\mathrm{C}\left[\mathrm{Gly}^{1}, \mathrm{DNal}^{6}\right]-\mathrm{GnRH}$ & $15 \pm 0 \cdot 50^{\mathrm{C} *}$ & $11 \cdot 4 \pm 1 \cdot 0^{\mathrm{e}, \mathrm{d}}$ \\
\hline$c\left[\beta \mathrm{Ala}^{1}, \mathrm{DTrp}^{6}\right]-\mathrm{GnRH}$ & $953 \pm 66^{\mathrm{e}_{*}}$ & $249 \pm 30^{f}$ \\
\hline $\mathrm{c}\left[\mathrm{Dava}^{1}, \mathrm{DNal}^{6}\right]-\mathrm{GnRH}$ & $381 \pm 72^{f *}$ & $0 \cdot 74 \pm 0 \cdot 11^{\mathrm{g}}$ \\
\hline $\mathrm{c}\left[\mathrm{Gaba}^{1}, \mathrm{DNal}^{6}\right]-\mathrm{GnRH}$ & $0 \cdot 22 \pm 0 \cdot 01^{\mathrm{a} *}$ & $5 \cdot 1 \pm 0 \cdot 80^{a}$ \\
\hline
\end{tabular}

Data are means \pm S.E.M. of three independent experiments in triplicate incubations. Means identified by different superscript letters in the same column are significantly $(P<0 \cdot 05)$ different. ${ }^{*} P<0.05$ vs rat GnRHR system. For abbreviations see Table 1.

hGnRHR may arise from the interaction of the peptide with amino acid residues or domains that are unique to the human receptor (e.g. at the exoloop 2 or intraloop 2, which share 76 and $62 \%$ amino acid identity with the corresponding domains in the rGnRHR); in this setting, the particular structure of the rGnRHR antagonist might ultimately determine a preference for binding to the active receptor conformation of the hGnRHR and to both the inactive and active conformations of the rat counterpart, as would be expected for antagonist analogues. In fact, in a number of $G$ protein-coupled receptors, including the GnRHR, mutations or species-dependent structural differences in either transmembrane domains (Strader et al. 1989, Claude et al. 1996, Noda et al. 1996, Groblewski et al. 1997, Han et al. 1997, Spivak et al. 1997), intraloops (Morin et al. 1998, Wurch et al. 1999) or exoloops (Sun et al. 2001) may be limiting, to a variable extent, the level of maximal stimulation. It should be emphasized, however, that the effects of the compounds tested may be cell-specific and that depending on the relative levels of receptor, $G$ proteins and other downstream effectors present in a particular tissue in vivo (i.e. the pituitary gland), their net effects observed might vary.

We noticed that some of the compounds tested (e.g. c $\left[\mathrm{Gly}^{1}, \mathrm{DNal}^{6}\right]-\mathrm{GnRH}$ and c[Eaca $\left.\left.{ }^{1}, \mathrm{DNal}^{6}\right]-\mathrm{GnRH}\right) \mathrm{did}$ not display the perfect sigmoidal IP stimulation exhibited by others; this was suggestive of a second low affinity binding site. The precise interaction of the ligand with the GnRHR is unknown and low-affinity interactions have been proposed in some tissues (Pahwa et al. 1991). It is also possible that this may reflect a non-specific interaction of a hydrophobic analogue at the very high dose $\left(10^{-5} \mathrm{M}\right)$ when this was observed.

Partial agonism is rare for GnRH analogues; in fact, this activity has largely been overlooked in the design of partial agonists for $\mathrm{GnRH}$, except for two reports emphasizing the critical role of $\mathrm{His}^{2}$ in activating the $\mathrm{GnRH}$ receptor (Vale et al. 1972) and head to tail cyclization (Rivier et al. 1986) that results in a steric constraint that may prevent the analogue from assuming the proper conformation for full receptor activation. Whereas we have found that the length of a bridge used to restrain a particular conformation in GnRH antagonists is critical for maximization of potency in vivo or binding affinity in vitro (Rivier et al. $2000 a, 2000 b, 2000 c$ ), we see little effect of bridge size (from Gly to $\varepsilon$-aminocaproic acid) in the binding properties of the head to tail bridged analogues (Table 2). This suggests that those spacers are not part of the pharmacophore and that the common amino acids assume a similar conformation independently from the bridge.

Interestingly, analogues constrained by the introduction of a lactam ring $\left(\mathrm{c}(4-10)\left[\mathrm{Asp}^{4}, \mathrm{DNal}^{6}, \mathrm{Dpr}^{10}\right]-\mathrm{GnRH}\right.$ and $\left.\mathrm{c}(4-10)\left[\mathrm{Dpr}^{4}, \mathrm{DNal}^{6}, \mathrm{Asp}^{10}\right] \mathrm{GnRH}\right)$ yielded full antagonists with both GnRHR systems. This is noteworthy since all other antagonists of $\mathrm{GnRH}$ have substitutions at any of the three positions $1-3$. It is therefore conceivable to propose two different approaches to the design of GnRH antagonists based on functional/structural modifications that ultimately yielded analogues such as cetrorelix, abarelix and degarelix. One approach is to introduce a lactam ring between the side chains of residues at positions 4 and 10 without modifying the pGlu-His-Trp $\mathrm{N}$-terminus. In fact, we show here for the first time that full antagonists with significant binding affinity are generated while keeping the N-terminal pGlu-His-Trp moiety intact. This can best be explained as the result of a conformational constraint imposed onto the whole molecule. The finding that the potency of some of the peptides to inhibit binding of radiolabelled buserelin did not absolutely correlate with IP production should not be surprising since it has been consistently documented that for both small and large polypeptide hormones, receptor binding and signal transduction may be dissociable functions (Coy et al. 1982, Valove et al. 1994).

Recent substitutions attempting to improve the binding affinity of the partial agonists described here included modifications at positions 5 and 6 using some of the optimized substitutions used in the design of the latest generation of GnRH antagonists (Jiang et al. 2001). Those analogues are all full antagonists. This does not imply that such compounds cannot be designed. There is no doubt that potent partial agonists may be useful in clinical practice, since they may provoke significant suppression of the hypothalamic-gonadotroph axis and allow endogenous oestrogen to remain at the level needed for maintenance of bone density and prevention of symptoms of oestrogen deficiency. For example, Horvath et al. (2004) have approached this challenge using low doses of the GnRH antagonist, cetrorelix. Their results suggest that cetrorelix in low doses induces only a partial pituitary-gonadal inhibition and might be indicated for 
treatment of endometriosis, leiomyomas and benign prostatic hyperplasia.

Whether the partial or the low-dose GnRH antagonist will prevail to obtain partial inhibition of the gonadal axis remains to be seen. It is conceivable that a partial agonist approach will lead to slow, in onset, but ultimately complete desensitization of the GnRHR, whereas the low dose of a GnRH antagonist will ultimately lead to early 'escape' and therefore to challenges in dosing.

\section{Funding}

This study was supported by grants HD-19899, RR-00163, HD-18185, HD-38899 and TW/HD-00668 from the National Institutes of Health, Bethesda, MD, USA (P M C), grant 2005/1/I/007 from the FOFOI-IMSS, Mexico (A L-M) and grant 45991-M from CONACyT, Mexico (A U-A). The authors declare that there is no conflict of interest that would prejudice the impartiality of this scientific work.

\section{References}

Belchetz PE, Plant TM, Nakai Y, Keogh EJ \& Knobil E 1978 Hypophysial responses to continuous and intermittent delivery of hypothalamic gonadotropin-releasing hormone. Science 202 631-633.

Bolonna AA \& Kerwin RW 2005 Partial agonism and schizophrenia. British Journal of Psychiatry 186 7-10.

Brink CB, Harvey BH, Bodenstein J, Venter DP \& Oliver W 2004 Receptor advances in drug action and therapeutics: relevance of novel concepts in G-protein-coupled receptor and signal transduction pharmacology. British Journal of Clinical Pharmacology 57 373-387.

Callahan MJ 2002 Irritable bowel syndrome neuropharmacology. A review of approved and investigational compounds. Journal of Clinical Gastroenterology 35 (Suppl 1) 58-67.

Chabbert-Buffet N, Olivennes F \& Bouchard P 2003 GnRH antagonists. Clinical Obstetrics and Gynecology 46 254-264.

Claude PA, Wotta DR, Zhang XH, Prather PL, McGinn TM, Erickson LJ, Loh HH \& Law PY 1996 Mutation of a conserved serine in TM4 of opioid receptors confers full agonistic properties to classical antagonists. PNAS 93 5715-5719.

Conn PM \& Crowley F 1991 Gonadotropin-releasing hormone and its analogues. New England Journal of Medicine 324 93-103.

Conn PM, Janovick JA, Stanislaus D, Kuphal D \& Jennes L 1995 Molecular and cellular bases of gonadotropin-releasing hormone action in the pituitary and central nervous system. Vitamins and Hormones 50 151-214.

Coy D, Hovart A \& Nekola M 1982 Peptide antagonists of LH-RH: large increases of antiovulatory activities produced by basic D-amino acids in the six position. Endocrinology 110 1445-1447.

Cusan L, Auclair C, Belanger A, Ferland L, Kelly PA, Seguin C \& Labrie F 1979 Inhibitory effects of long-term treatment with a LHRH agonist on the pituitary-gonadal axis in male and female rats. Endocrinology 104 1369-1376.

DeFazio J, Meldrum DR, Laufer L, Vale W, Rivier J, Lu JK \& Judd HL 1983 Induction of hot flashes in premenopausal women treated with a long-acting GnRH agonist. Journal of Clinical Endocrinology and Metabolism 56 445-448.
Doggrell SA 2004 Telmisartan - killing two birds with one stone. Expert Opinion in Pharmacotherapy 11 2397-2400.

Emons G, Ortmann O, Schulz K-D \& Schally AV 1997 Growth-inhibitory actions of analogues of luteinizing hormone releasing hormone on tumor cells. Trends in Endocrinology and Metabolism 8 355-362.

Filicori M 1994 Gonadotrophin-releasing hormone agonists. A guide to use and selection. Drugs 48 41-58.

Fogelman I 1992 Gonadotropin-releasing hormone agonists and the skeleton. Fertility and Sterility 57 715-724.

Frolund B, Ebert B, Kristiansen U, Liljefors T \& Krogsgaard-Larsen P $2002 \mathrm{GABA}(\mathrm{A})$ receptor ligands and their therapeutic potentials. Current Topics in Medicinal Chemistry 8 817-832.

Gao ZG \& Jacobson KA 2004 Partial agonists for A(3) adenosine receptors. Current Topics in Medicinal Chemistry 4 855-862.

Groblewski T, Maigret B, Larguier R, Lombard C, Bonnafous JC \& Marie J 1997 Mutation of Asn ${ }^{111}$ in the third transmembrane domain of the $\mathrm{AT}_{1 \mathrm{~A}}$ angiotensin II receptor induces its constitutive activation. Journal of Biological Chemistry 272 1822-1826.

Han M, Lou J, Nakanishi K, Sakmar TP \& Smith SO 1997 Partial agonist activity of 11-cis-retinal in rhodopsin mutants. Journal of Biological Chemistry 272 23081-23085.

Horvath J E, Toller GL, Schally AV, Bajo AM \& Groot K 2004 Effect of long-term treatment with low doses of the LHRH antagonist Cetrorelix on pituitary receptors for LHRH and gonadal axis in male and female rats. PNAS 101, 4996-5001.

Huckle WR \& Conn PM 1987 The use of lithium in measurement of stimulated pituitary inositol phospholipid turnover. Methods in Enzymology 141 149-155.

Jiang G, Stalewski J, Galyean R, Dykert J, Schteingart C, Broqua P, Aebi A, Aubert ML, Semple G, Robson P et al. 2001 GnRH antagonists: a new generation of long acting analogues incorporating urea functions at positions 5 and 6. Journal of Medicinal Chemistry 44 453-467.

Johansen JS, Riis BJ, Hassager C, Moen M, Jacobson J \& Christiansen C 1988 The effect of gonadotropin-releasing hormone agonist analog (nafarelin) on bone metabolism. Journal of Clinical Endocrinology and Metabolism 67 701-706.

Karten M J \& Rivier JE 1986 GnRH analog design structure-function studies toward the development of agonists and antagonists: rationale and perspective. Endocrine Reviews 7 44-66.

Kiesel LA, Rody A, Greb RR \& Szilágy A 2002 Clinical use of GnRH analogues. Clinical Endocrinology 56 677-687.

Knobil E 1974 On the control of gonadotropin secretion in the rhesus monkey. Recent Progress in Hormone Research 30 1-46.

Lieberman JA 2004 Dopamine partial agonists: a new class of antipsychotic. CNS Drugs 18 251-267.

Lipworth BJ \& Grove A 1997 Evaluation of partial $\beta$-adrenoceptor agonist activity. British Journal of Clinical Pharmacology 43 9-14.

Matta WH, Shaw RW, Hesp R \& Kats D 1987 Hypogonadism induced by luteinizing hormone releasing hormone agonist analogues: effect on bone density in premenopausal women. British Medical Journal 294 1523-1524.

Millar RP, Lu Z-L, Pawson AJ, Flanagan CA, Morgan K \& Maudsley SR 2004 Gonadotropin-releasing hormone receptors. Endocrine Reviews 25 235-275.

Morin D, Cotte N, Balestre MN, Mouillac B, Manning M, Breton C \& Barberis C 1998 The D136A mutation of the V2 vasopressin receptor induces a constitutive activity which permits discrimination between antagonists with partial agonist and inverse agonist activities. FEBS Letters 441 470-475.

Noda K, Feng YH, Liu XP, Saad Y, Husain A \& Karnik SS 1996 The active state of the $\mathrm{AT}_{1}$ angiotensin receptor is generated by angiotensin II induction. Biochemistry 35 16435-16442.

Ortmann O, Weiss JM \& Diedrich K 2002 Gonadotrophin-releasing hormone $(\mathrm{GnRH})$ and $\mathrm{GnRH}$ agonists: mechanisms of action. Reproductive BioMedicine Online 5 (Suppl 1) 1-7. 
Pahwa GS, Kullander S, Vollmer G, Oberheuser F, Knuppen R, Emons G 1991 Specific low affinity binding sites for gonadotropin-releasing hormone in human endometrial carcinomata. European Journal of Obstetrics and Gynecology and Reproductive Biolology 41 135-142.

Pierce SJ, Gazvani R \& Farguharson RG 2000 Long-term use of gonadotropin-releasing hormone analogs and hormone replacement therapy in the management of endometriosis: a randomized trial with a 6-year follow up. Fertility and Sterility 74 964-968.

Pliska V 1999 Partial agonism: mechanisms based on ligand-receptor interactions and on stimulus-response coupling. Journal of Receptor and Signal Transduction Research 19 597-629.

Reynolds GP 2004 Receptor mechanisms in the treatment of schizophrenia. Journal of Psychopharmacology 18 340-345.

Rivier J, Varga J, Porter J, Perrin M, Haas Y, Corrigan A, Rivier C, Vale W, Struthers S \& Hagler A 1986 Potent conformationally constrained analogs of GnRH. The Ninth American Peptide Symposium, Toronto, Canada, pp 541-544.

Rivier JE, Jiang G, Struthers RS, Koerber SC, Porter J, Cervini LA Kirby DA, Craig AG \& Rivier CL 2000a Design of potent dicyclic $(1-5 / 4-10)$ gonadotropin releasing hormone $(\mathrm{GnRH})$ antagonists. Journal of Medicinal Chemistry 43 807-818.

Rivier JE, Porter J, Cervini LA, Lahrichi SL, Kirby DA, Struthers RS, Koerber SC \& Rivier CL $2000 b$ Design of monocyclic (1-3) and dicyclic (1-3/4-10) gonadotropin releasing hormone $(\mathrm{GnRH})$ antagonists. Journal of Medicinal Chemistry 43 797-806.

Rivier JE, Struthers RS, Porter J, Lahrichi SL, Jiang G, Cervini LA, Ibea M, Kirby DA, Koerber SC \& Rivier CL 2000c Design of potent dicyclic (4-10/5-8) gonadotropin releasing hormone $(\mathrm{GnRH})$ antagonists. Journal of Medicinal Chemistry 43 784-796.

Santen RJ \& Bardin CW 1973 Episodic luteinizing hormone secretion in man: pulse analysis, clinical interpretation, and physiological mechanisms. Journal of Clinical Investigation 52 2617-2628.

Spivak CE, Beglan CL, Seidleck BK, Hirshbein LD, Blaschak CJ, Uhl GR \& Surratt CK 1997 Naloxone activation of $\mu$-opioid receptors mutated at a histidine residue lining the opioid binding cavity. Molecular Pharmacology 52 983-992.

Strader CD, Candelore MR, Hill WS, Dixon RA \& Sigal IS 1989 A single amino acid substitution in the $\beta$-adrenergic receptor promotes partial agonist activity from antagonists. Journal of Biological Chemistry 264 16470-16477.

Sun Y-M, Flanagan CA, Illing N, Ott TR, Sellar R, Fromme BJ, Hapgood J, Sharp P, Seaflon SC \& Millar RP 2001 A chicken gonadotropin-releasing hormone receptor that confers agonist activity to mammalian antagonists. Journal of Biological Chemistry 276 7754-7761.

Tummon IS, Ali A, Pepping ME, Radwanska E, Binor Z \& Dmowski WP 1988 Bone mineral density in women with endometriosis before and during ovarian suppression with gonadotropin-releasing hormone agonists or danazol. Fertility and Sterility 49 792-796.

Ulloa-Aguirre A \& Timossi C 2000 Biochemical and functional aspects of gonadotropin-releasing hormone and gonadotropins. Reproductive Biomedicine Online 1 48-62.

Vale W, Grant G, Rivier J, Monahan M, Amoss M, Blackwell R, Burgus R \& Guillemin R 1972 Synthetic polypeptide antagonists of the hypothalamic luteinizing hormone releasing factor. Science 176 933-934.

Valove FM, Finch C, Anasti JN, Froehlich J \& Flack MR 1994 Receptor binding and signal transduction are dissociable functions requiring different sites on follicle-stimulating hormone. Endocrinology 135 2657-2661.

Wurch T, Colpaert FC \& Pauwels PJ 1999 G-protein activation by putative antagonists at mutant $T h{ }^{373}$ Lys $\alpha_{-}{ }_{2 \mathrm{~A}}$ adrenergic receptors. British Journal of Pharmacology 126 939-948.

Received in final form 15 February 2006

Accepted 23 February 2006

Made available online as an Accepted Preprint 24 February 2006 